\title{
ИЗМЕНЕНИЕ ОБРАЗОВАТЕЛЬНОЙ СРЕДЫ КРАСНОДАРСКОГО КРАЯ В 1953-1970-Е ГОДЫ ХХ ВЕКА
}

\section{CHANGES IN THE EDUCATIONAL ENVIRONMENT OF THE KRASNODAR TERRITORY IN THE 1953-1970S OF THE XX CENTURY}

\section{E. Moskalenko}

Summary: The period 1953-1970-ies of the twentieth century is characterized by significant political, state and social changes in the Soviet state, understanding the relationship between the economic success of the country and the rise in the level of education of Soviet citizens. The leadership of the USSR at that time very well understood that the leading positions in the world will be taken by countries with powerful intellectual potential. Education in the USSR has always been a priority. In 1949, the course was taken for universal seven-year education, followed by the implementation of universal secondary education for young people. This article discusses the main aspects of changes in the educational environment of the Krasnodar territory in the 1953-1970-ies of the XX century. At the end of the article, conclusions were made based on the results of the study.

Keywords: education, educational environment, educational system, social situation, educational reforms.

\author{
Москаленко Елена Владимировна \\ ФГБОУ ВО «Кубанский Государственный Университет» \\ Helen-345@mail.ru
}

Аннотация: Период 1953-1970-е годы XX века характеризуется значительными политическими, государственными и общественными изменениями в советском государстве, пониманием взаимосвязи экономического успеха страны с подъемом уровня образования советских граждан. Руководство СССР на тот момент очень хорошо понимало, что передовые позиции в мире займут страны, обладающие мощным интеллектуальным потенциалом. Вопросы образования в СССР всегда были в приоритете. В 1949 году был взят курс на всеобщее семилетнее образование, а вслед за ним - на осуществление всеобщего среднего образования молодежи. В данной статье рассмотрены основные аспекты изменения образовательной среды Краснодарского края в 1953-1970-е годы XX века. В конце статьи были сделаны выводы по итогам проведенного исследования.

Ключевые слова: образование, образовательная среда, система образования, социальная ситуация, реформы образования.
Д есталинизация после 1953-го года и процессы обновления политической и общественной жизни страны объективно создавали условия успешного жения её в сторону социального прогресса. При этом необходимо помнить, что в ходе реформ 1950-х годов развитие сферы образования было все-таки недостаточным, а поставленные задачи не в полной мере содействовали решению существующих проблем, одна из которых заключалась в недостаточном финансировании.

Для сравнения, в годы восстановления после немецко-фашистской оккупации на просвещение выделялось $14 \%$ государственного бюджета (что стало наиболее высоким показателем в истории (ССР) [1], а в 1950-е гг. удельный вес части национального дохода, направляемой на финансирование образования, снизился с 10,24 $\%$ до $6,1 \%$ [22].

В связи с отсутствием финансирования в начале 1950-х годов произошел отказ от масштабного образовательного проекта - перехода в течение десяти лет к среднему всеобщему образованию.
Между тем, проект был направлен на радикальное изменение всей системы образования и социальной ситуации в стране в целом: школа становилась учреждением, системно готовящим молодежь к взрослой жизни, а не отдельную часть учащихся к продолжению обучения в техникумах и вузах.

К задаче среднего всеобуча вернулась новая Программа КПСС, которая предполагала два этапа своего разрешения: 1960-е годы - процесс всеобщего среднего образования детей школьного возраста, 1970-е годы обучение станет обязательным для всего населения.

Несмотря на объективно существующие неблагоприятные тенденции развития государства в 1950-1960-е годы, отечественная система образования стремится к последовательному совершенствованию. Реформы 1959-1962-го годов способствовали ее выходу на качественно новые рубежи.

Значительных успехов в развитии системы образования в рассматриваемый период достиг и Краснодарский край, передовой аграрный регион. В частности, к 1966му году в крае была в основном реализована государ- 
ственная программа по ликвидации безграмотности и малограмотности среди взрослого населения СССР. При этом целый ряд сельских районов даже отрапортовал руководству, что «неграмотных и малограмотных граждан нет». Однако подобная отчетность вызывала недоверие руководства края. Так, Краснодарским сельским крайкомом отмечалась «беспринципность в учете малограмотного и неграмотного населения», фиксировались факты занижения отчетных цифр в десятки раз [23;24;25].

В целом в крае наблюдается значительный прогресс в развитии школьной системы. Так, уже в годы первой семилетки (1958-1965 годы) в Краснодарском крае модернизирована основная часть старых образовательных учреждений, созданы 62 новые общеобразовательные школы, построено 960 школьных зданий на 239319 учебных мест.

В основном такой подъем системы образования был обеспечен всемерным поощрением так называемого «инициативного» строительства школ и интернатов методом «народной стройки» за счет активного привлечения финансовых и материальных средств колхозов, совхозов и промышленных предприятий. Например, программа расширения действующих школ, позволившая к уже указанным выше ученическим местам добавить еще 32 888, финансировалась преимущественно колхозами. За счет же плановых государственных вложений на территории Краснодарского края было выстроено только 154 здания для осуществления образовательной деятельности на 89625 учебных мест. Совершенно очевидно, что рост материальной базы способствовал увеличению количества обучающихся. Так, за это время число учащихся общеобразовательных школ возросло с 487,7 до 736,5 тысяч человек. Контингент учащихся вечерних школ также увеличился с 27,7 до 61,6 тысяч обучающихся, а школ-интернатов с 5 до 10,5 тысяч человек. Безусловным достижением можно считать и рост количества учителей. В 1958-1965 годах их число возросло с 29430 до 38214 человек [7].

В рассматриваемый нами период перед образованием была поставлена новая задача всеобщего восьмилетнего обучения. И следует отметить, что к началу восьмой пятилетки задача успешно осуществлялась. Значительная часть молодежи оказалась вовлечена в образовательный процесс, что в целом благоприятно сказывалось на социальной ситуации в государстве вообще и регионе в частности. Процент молодежи, получающей образование в Краснодарском крае в тот период, составил 73 \% [6]. Однако по-настоящему активно задачи всеобуча начали решаться лишь на рубеже 1960-1970-х годов. Несмотря на это, уже в 1960-е годы существенно увеличился прием обучающихся в техникумы и вузы. К 1966-му году он практически удвоился по стране [20]. Преимущество в соответствии с Законом о школе (1958 год) получили вечерняя и заочная формы подготовки.

На основании постановления Совета Министров СССР от 18 сентября 1959 года «Об участии промышленных предприятий, совхозов и колхозов в комплектовании вузов и техникумов в подготовке специалистов для своих предприятий» был установлен порядок направления работающей молодежи на обучение.

Несмотря на положительную динамику в развитии системы образования, общая ситуация оставалась достаточно сложной. С 1963-го года происходит резкое снижение финансирования государством средних специальных учебных заведений. Общеобразовательные школы испытывают огромные трудности. Масштабное строительство образовательных учреждений не могло пока исправить сложившейся ситуации: 60 \% школ, действовавших в 1965-м году, было построено еще до 1940-го года; в том числе: 37 \% - до 1918 года и $23 \%$ в 1918-1940-х годах. Одна школа могла располагаться в нескольких корпусах, иногда даже в 16-ти. 78 школ находилось в аварийном состоянии, которое оценивалось как угрожающее «жизни и здоровью учащихся». Краевым отделом народного образования сообщалось: «Промедление с решением этого вопроса может привести к гибели учащихся». Обычной в школах была ситуация с многосменностью занятий, недостатком мебели и наличием в некоторых школах керосинового освещения. Нарушение элементарных норм привело к тому, что к середине 1960-х годов появилась негативная тенденция роста числа учащихся с пониженным зрением, искривленным позвоночником и подобным [5].

Ситуация осложнялась еще и тем, что финансирование колхозами постройки образовательных учреждений стало ограничиваться, по этой причине со второй половины 1960-х годов восстановление и строительство объектов народного образования было возложено на государственные организации, работающие по договорам с колхозами, также возникла необходимость «решить вопрос о существенном укреплении производственной базы межколхозных строительных организаций» [23].

Особого внимания заслуживает проблема кадрового обеспечения школ. С середины 1960-х годов в школах повсеместно отмечается значительная нехватка кадров, которая возникает по ряду объективных причин: недостаточная привлекательность учительского труда, низкий уровень заработной платы, бытовая неустроенность педагогов - примерно треть сельских учителей проживала на частных квартирах. На Кубани в годы семилетки удельный вес учителей с педагогическим стажем менее 10 лет сократился с 49 \% до 33,3 \%, наибольшее падение приходилось на группу со стажем от 5 до 10 лет [4]. В целом отмечается отсутствие в школе молодых кадров, а также значительное снижение количества опытных пе- 
дагогов, пришедших на работу в школы накануне или в первые годы семилетки.

Стоит сказать о том, что значительная часть учителей имела среднее или даже незаконченное среднее образование. Среди руководства школой наблюдается такая же ситуация: директоров школ и их заместителей к категории «недостаточно профессионально соответствующих своей должности» в 1966-м году в Краснодарском крае относилось 18 человек с общим средним и более 400 со средним специальным образованием [24].

В связи с этим руководством государства был взят курс на профессионализацию системы образования, осуществление которой началось во время реформы 1958-го года. Предполагалось, что средняя общеобразовательная школа совместит процесс обучения и производственным трудом. Эта идея активно претворялась в жизнь, однако уже к середине 1960-х годов стало ясно, что средняя школа не решает возложенной на нее задачи - выполнение функций профессионального технического образования. Хотя данный принцип обучения не подвергается критике и сегодня. В результате к концу 1960-х годов в государстве развернулась масштабная программа развития системы средних профессионально-технических училищ.

Курс на профессионализацию образования в целом оказал серьезное положительное и долговременной влияние на общеобразовательную школу. Так, например, в рамках профессионализации особое значение пробрела деятельность по организации групп и школ продленного дня, призванных обеспечить занятость детей и подростков в то время, когда их родители находятся на работе (постановление ЦК КПСС и Совмина СССР от 15.02.1960 года «Об организации школ с продленным днем»).

В Краснодарском крае в 1965-1966 учебном году учащихся 1-8-х классов, охваченных группами продленного дня, насчитывалось от 31 тыс. до 39 тыс. человек, а в 1970-1971 учебном году - уже 72-75 тыс. человек. Введение групп и школ продленного дня в известной степени актуализировало вопрос о питании учащихся [2].

Выделяя специфические черты анализируемого период нельзя не остановиться на зародившемся в это время явлении, негативно повлиявшем на развитие отечественного школьного образования. Речь идет о так называемой «борьбе» за повышение успеваемости учащихся.

В исторических условиях «строительства коммунизма» и формирования соответствующей идеологии от педагогов школ все чаще требовалось уделять внимание «воспитывающему» характеру оценки знаний. Учителя обязаны были сделать все возможное, чтобы не ставить плохих отметок даже при условии явного незнания учебного материала. Руководство школ, отделов народного образования вело жесткую борьбу с большинством учителей, стремившихся к объективной оценке знаний обучающихся. Ситуация доходила о того, что уровень квалификации и профессиональных знаний педагогов ставился в прямую зависимость от наличия в классах неуспевающих учащихся. Как результат, отмечается рост учащихся, успевающих на «хорошо» и «отлично», а также предупреждение второгодничества. Эти два явления стали настоящей проблемой советского образования.

На территории Краснодарского края также отмечен рост успеваемости учащихся: в годы семилетки успеваемость поднялась с отметки в среднем 2,8 \% до уровня 96,8 \% [3]. Подобное понимание задачи повышения «качества знаний» в целом отрицательно влияло на образовательный процесс.

Однако было бы неправильным не отмечать на фоне большого количества негативных явление все-таки значительной деятельности по развитию системы образования и предупреждению ее недостатков. Очень настойчиво велась работа по развитию материальной и учебной базы, общему наведению порядка. Доказательством тому являются факты, содержащиеся в документах 1950-1960-х годов. Именно в это период началась реализация крупномасштабных проектов, предусматривавших резкое повышение всеобщей грамотности населения, в том числе и в сельской местности.

Очевидно, что образовательная политика того периода, принципиально изменившая отечественную образовательную среду, должна рассматриваться как важная составляющая общегосударственной политики восстановления эквивалентных отношений между городом и деревней. В то же время она позволила эффективно мобилизовать внутренние ресурсы сельского сообщества.

В 1960-1970-е гг. в системе образования СССР появились новые типы образовательных учреждений, увеличилось количество полных средних школ и десятилетним сроком обучения. Параллельно идет процесс уменьшения числа школ-восьмилеток и реструктуризация их в школы с десятилетним обучением. В сельской местности остаются малокомплектные школы для того, чтобы обеспечить обучение детей без отрыва от семьи. Заметная акселерация в 1970-х годах обусловила переход с четырехлетнего на трехлетнее начальное обучение без снижения объема получаемых детьми знаний и при усложнении теоретического уровня начального обучения. В целом же в этот период укреплялась материальная база школ, что отвечало задачам трудового обучения и политехнического образования; возникали межшкольные учебно-производственные комбинаты 
(УПК), где обучающиеся проходили трудовую подготовку предпрофессионального характера.

Таким образом, рассматривая культурно-образовательное развитие Кубани в 1953-1970-е годы, нужно выделить ряд важных моментов. Как и в целом в стране, на территории Краснодарского края период «эпохи застоя» отличался противоречивостью. С одной стороны, происходили масштабные достижения в области науки, образования, просвещения; отмечен значительный рост числа обучающихся и повышение качества обучения в целом; возросла роль культурно-массовой работы, по- являлись выдающиеся деятели искусства, творческие коллективы, известные не только в СССР, но и далеко за его пределами. Но при этом, с другой стороны, наблюдается рост социальной несправедливости в сфере высшего образования, слабая техническая оснащенность и отставание учебно-образовательного процесса от требований реальной жизни. Культурная и образовательная сферы жизни советского человека как один из важнейших «идеологических фронтов» коммунистической партии подвергались чрезмерной идеологизации и опеке со стороны партийных органов, что, безусловно, отрицательно сказывалось на их качестве и потенциале.

1. Большевик. - 1947. - № 11. - С. 11.

ЛИТЕРАТУРА

2. ГАКК. Ф. Р-1561. ОП. 2. Д. 612. Л. 3; Д. 853. Л. 4; Д. 637. Л. 27.

3. ГАКК. Ф.Р-1561. Оп. 2. Д. 612.Л. 6.

4. ГАКК. Ф.Р-1561. ОП. 2. Д. 612. Л.Л. 6-7.

5. ГАКК. Ф. Р-1561. ОП. 2. Д. 637.Л.Л. 24-28.

6. ГАКК. Ф. Р-1561. Оп. 2. Д. 853. - Л. 4.

7. ГАКК. Ф.Р-1561. Оп. 2. Д. 612. Л.Л. 5-13.

8. ГАКК. Ф.Р-1561. ОП. 5. Д. 112.Л. 188.

9. ГАКК. Ф.Р-1561. Оп. 5. Д. 112. Л. 2-22, 23-30, 71-81, 91-111, 113-114, 127-130, 135-145, 185-198, 208-212.

10. ГАКК. Ф.Р-1561. ОП. 5. Д. 112. Л. 28.

11. ГАКК. Ф.Р-1561. ОП. 5. Д. 112. Л. 72.

12. ГАКК. Ф.Р-1561. Оп. 5. Д. 113. Л. 26.

13. ГАКК. Ф.Р-1561. Оп. 5. Д. 113. Л. 26-30, 35.

14. ГАКК. Ф.Р-1561. Оп. 5. Д. 113. Л. 35, 67-74, 75-78, 104-110, 116-117, 139-143.

15. ГАКК. Ф.Р-1893. ОП. 1. Д. 7.Л. 107, 108.

16. ГАКК. Ф.Р-1893. ОП. 1. Д. 7. Л. 138, 157, Д. 14. Л. 56-57.

17. ГАКК. Ф.Р-1893. Оп. 1.Д. 7. Л. 47-50, 59-60.

18. ГАКК. Ф.Р-1893. Оп. 1.Д. 1, 2 ; Д. 24, 25, 26, $27,28$.

19. Зубкова Е.Ю. Послевоенное советское общество: политика и повседневность. 1945-1953 гг. [Электронный ресурс] / E.Ю. 3yбкова. - URL: https://docplayer. ru/58983131-Elena-zubkova-poslevoennoe-sovetskoe-obshchestvo-politika-i-povsednevnost.html.

20. Народное образование, наука и культура в СССР [Электронный ресурс]. - М.: Статистика, 1971. - 403 c. - URL: http://alcdata.narod.ru/Nar_0brazov_1971/ Nar_Obrazov_1971.pdf.

21. Правофланговые 12-й пятилетки народного образования Кубани. Краснодар, 1987. ЦДНИИКК. Ф. 1774-Р. Оп. 2. Д. 1408. Л. $290-316$.

22. Проблемы экономики и планирования образования: сборник трудов лаб. / под ред. канд. экон. наук С.Л. Костаняна; М-во просвещения РСФСР. Моск. гос. пед. ин-т им. В.И. Ленина. Проблемная лаб.соц.-экон. исследований в области нар. образования. - М., 1973. - 235 с. - С. 6-7.

23. ЦДНИКК. Ф. 1774-А. Оп. 12. Д. 219. Л. 1.

24. ЦДНИКК. Ф. 1774-А. Оп. 13. Д. 183. - Л.Л. 2-3.

25. ЦДНИКК. Ф.1774-А. Оп. 11. Д. 172. Л.Л. 1, 2, 5, 7, 30.

(с) Москаленко Елена Владимировна (Helen-345@mail.ru). 